\section{Caribbean Wellness Day: mobilizing a region for chronic noncommunicable disease prevention and control}

\section{T. Alafia Samuels ${ }^{1,2}$ and Henry Fraser ${ }^{1}$}

Suggested citation: Samuels TA, Fraser H. Caribbean Wellness Day: mobilizing a region for chronic noncommunicable disease prevention and control. Rev Panam Salud Publica. 2010; 28(6):472-9.

SYNOPSIS

The member states of the Caribbean Community (CARICOM) have the highest prevalence of chronic noncommunicable diseases (CNCDs) in the Americas. The CARICOM heads of government issued the Port-of-Spain Declaration "Uniting to Stop the Epidemic of Chronic NonCommunicable Diseases in the Caribbean," mandating intersectoral, population-based approaches and commemoration of the summit on the second Saturday in September as "Caribbean Wellness Day (CWD)." CWD, inaugurated in September 2008, is designed to strengthen public, private, and civil society partnerships and to promote multicountry, multisectoral activities in support of wellness. By 2009, the second year of the celebrations, 18 of the 20 CARICOM countries embraced and celebrated with multifaceted, multifocal activities, using this as a catalyst for sustained physical activities, healthy food choices, and health screening in a smokefree environment. Organizational support and Caribbean branding of products came from the Pan American Health Organization/World Health Organization and CARICOM. Outcomes will be measured by input and process indicators and $C N C D$ risk factor surveillance.

Key words: chronic disease; health promotion; community participation; public-private partnership; West Indies.

\footnotetext{
1 Faculty of Medical Sciences, University of the West Indies, Bridgetown, Barbados, West Indies. Send correspondence to: Thelma Alafia Samuels, alafiasam@hotmail.com, alafia.samuels@cavehill.uwi.edu

2 Caribbean Community (CARICOM) Secretariat, Georgetown, Guyana.
}

The Caribbean Community (CARICOM) includes mainland countries Guyana, Suriname, and Belize and the islands of Antigua and Barbuda, Bahamas, Barbados, Dominica, Grenada, Haiti, Jamaica, Montserrat, Saint Kitts and Nevis, Saint Lucia, Saint Vincent and the Grenadines, and Trinidad and Tobago. The five United Kingdom Overseas Territories-Anguilla, Bermuda, British Virgin Islands, Cayman Islands, and Turks and Caicos Islands-are associate members (1).

With the exception of Haiti, they are middleincome developing countries with a population of 7 million, mean per capita income of US\$7 005, and mean life expectancy of 72 years (Table 1) $(2,3)$.

The Caribbean has the highest prevalence of chronic noncommunicable diseases (CNCDs) in the region of the Americas (2). Diabetes mortality in Trinidad and Tobago and in Saint Vincent and the Grenadines is $600 \%$ higher than in North America (United States and Canada), and cardiovascular disease mortality rates in Trinidad and Tobago, Guyana, and Suriname are $84 \%, 62 \%$, and $56 \%$ higher, respectively, than in North America (Figure 1). In Barbados, the prevalence rate and mortality rate of diabetesrelated lower extremity amputations are among the highest in the world $(4,5)$.

Globally, CNCD mortality in middle-income developing countries is projected to increase to $61 \%$ by 2015 and $75 \%$ by $2030(6,7)$. Currently, almost half of CNCD deaths occur in people $<70$ years old, with a quarter $<60$ years old, adversely affecting the economy at the individual, household, and national levels (8). CNCDs are more prevalent among the poor, and the decline in cardiovascular diseases in higherincome countries occurs later among the poor (9). Addressing chronic diseases is thus a challenge for the core principles of social justice, equity, and access.

\section{RISK FACTORS}

The social determinants of health-urbanization, globalization, and education-plus aging of the population set the stage for unhealthy eating, physical inactivity, tobacco use, and alcohol abuse. These common risk factors are associated with the biological risk factors for CNCDs of hypertension, high blood glucose, abnormal lipid levels, and obesity (10).

Most of the populations in CARICOM countries are of African descent, with a high prevalence of hypertension, and the risk factors of excessive salt consumption and obesity (11) are accepted as cultural norms. Among adults 25-74 years old, the ageadjusted prevalence rates of hypertension $(\geq 160 / 95$ $\mathrm{mmHg}$ ) for Jamaica, Saint Lucia, and Barbados were $17.5 \%, 18.3 \%$, and $21.5 \%$, respectively, with men 
TABLE 1. Selected demographic indicators for Caribbean Community member states, 2003-2007

\begin{tabular}{|c|c|c|c|c|c|}
\hline Country & $\begin{array}{c}\text { Total } \\
\text { population } \\
\text { (thousands), } \\
2003-2005\end{array}$ & $\begin{array}{c}\text { Total } \\
\text { fertility rate }^{\mathrm{a}} \\
\text { (children/woman), } \text {, } \\
\text { 2003-2005 }\end{array}$ & $\begin{array}{c}\text { Urban } \\
\text { population } \\
(\%), \\
2003-2005\end{array}$ & $\begin{array}{c}\text { Life } \\
\text { expectancy } \\
\text { at birth }^{\mathrm{a}} \\
\text { (years), } \\
\text { 2003-2005 }\end{array}$ & $\begin{array}{c}\text { Gross national } \\
\text { income } \\
\text { per capita, } \\
\text { Atlas method } \\
\text { (current US\$), } 2007\end{array}$ \\
\hline Anguilla & 14 & 1.8 & 100.0 & 81.0 & NA \\
\hline Antigua and Barbuda & 86 & 2.1 & 30.4 & 75.0 & 12610 \\
\hline Bahamas & 342 & 2.0 & 83.9 & 74.0 & 17160 \\
\hline Barbados & 256 & 1.5 & 40.3 & 77.5 & 9330 \\
\hline Bermuda & 68 & 2.0 & 100.0 & 80.0 & 32760 \\
\hline Belize & 307 & 2.8 & 52.2 & 76.6 & 3760 \\
\hline British Virgin Islands & 24 & 1.7 & 40.8 & 77.0 & NA \\
\hline Cayman Islands & 49 & 1.9 & 100.0 & 80.0 & NA \\
\hline Dominica & 73 & 2.1 & 74.3 & 76.0 & 4500 \\
\hline Grenada & 104 & 2.3 & 30.9 & 75.6 & 5350 \\
\hline Guyana & 762 & 2.3 & 28.4 & 67.4 & 1170 \\
\hline Haiti & 10033 & 3.4 & 48.2 & 61.5 & 520 \\
\hline Jamaica & 2719 & 2.4 & 53.5 & 72.1 & 4420 \\
\hline Montserrat & 5 & 1.2 & 14.1 & 73.0 & NA \\
\hline Saint Kitts and Nevis & 40 & 2.3 & 32.4 & 73.0 & 9860 \\
\hline Saint Lucia & 172 & 2.0 & 27.9 & 74.0 & 5310 \\
\hline Saint Vincent and the Grenadines & 109 & 2.1 & 47.4 & 71.8 & 4890 \\
\hline Suriname & 520 & 2.4 & 75.3 & 69.2 & 4450 \\
\hline Trinidad and Tobago & 1339 & 1.6 & 13.5 & 69.7 & 14480 \\
\hline Turks and Caicos Islands & 23 & 3.0 & 92.5 & 75.0 & NA \\
\hline
\end{tabular}

Note: NA: not available from these United Kingdom Overseas Territories.

a Source: PAHO health situation in the Americas, basic indicators, 2009. http://new.paho.org/hq/index.php?option=com_content\&task=view\&id=220\&ltemid=317.

b Source: World Bank data and statistics.

younger than 55 years least likely to have their hypertension treated and controlled (12).

Alcohol abuse among men is a significant and growing public health challenge (Table 2 ) with $4.5 \%$ of attributable deaths in this region compared with $1.5 \%$ globally (13).

In CARICOM member states, consumption of fats and sugars is $160 \%$ and $250 \%$ of requirements, respectively (14). Physical inactivity levels in Jamaica, Trinidad and Tobago, and Guyana averaged 38\%, 39\%, and $56 \%$, respectively, with greater levels of physical inactivity among the urban population and among professionals and clerical staff in all countries (15). Coupled with low consumption of fruits and vegetables, these factors drive the obesity epidemic (Table 2).

In middle-income developing countries, high blood pressure accounts for $17.2 \%$ of deaths, tobacco $10.8 \%$, obesity $6.7 \%$, and physical inactivity $6.6 \%$ (16). A similar pattern has been demonstrated in four Caribbean countries (Figure 2).

FIGURE 1. Adjusted diabetes mellitus, cardiovascular disease (CVD) (ischemic heart disease [IHD] and cerebrovascular accident [CVA]), cancer, and communicable disease mortality per 100000 population, selected Caribbean Community (CARICOM) countries with population > 100000 and North America (United States and Canada), 2003-2005

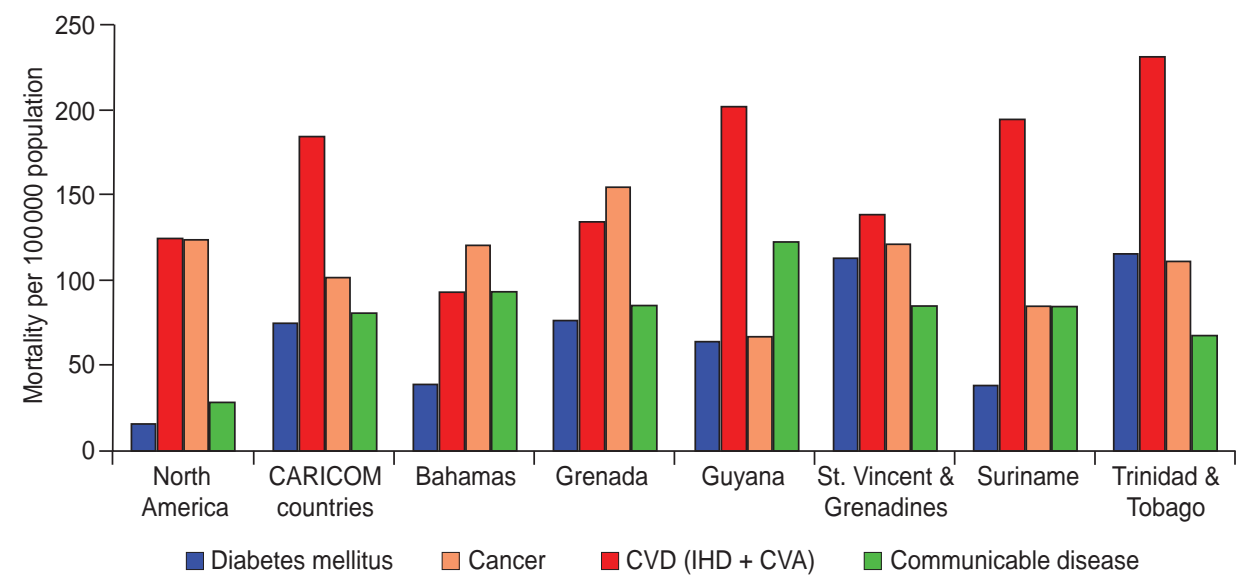

Source: PAHO health situation in the Americas: basic indicators, 2009. 
TABLE 2. Selected risk factors from STEPwise approach to surveillance chronic noncommunicable diseases risk factor surveys, 2007-2009

\begin{tabular}{|c|c|c|c|c|}
\hline Risk factor & $\begin{array}{c}\text { Saint } \\
\text { Kitts } \\
(n=1443)\end{array}$ & $\begin{array}{c}\text { British } \\
\text { Virgin } \\
\text { Islands } \\
(n=1105)\end{array}$ & $\begin{array}{c}\text { Barbados } \\
(n=1282)\end{array}$ & $\begin{array}{c}\text { Dominica } \\
(n=1059)\end{array}$ \\
\hline \multicolumn{5}{|c|}{$\begin{array}{l}\text { Obesity, body } \\
\text { mass index } \geq 30\end{array}$} \\
\hline Male (\%) & 38 & 28 & 20 & 9 \\
\hline Female (\%) & 52 & 44 & 35 & 33 \\
\hline \multicolumn{5}{|c|}{ Daily tobacco use } \\
\hline Male (\%) & 11 & 9 & 11 & 10 \\
\hline Female (\%) & 1 & 4 & 1 & 1 \\
\hline \multicolumn{5}{|l|}{$\begin{array}{l}\text { Alcohol use } \geq 4 \\
\text { days/week }\end{array}$} \\
\hline Male (\%) & 13 & 14 & 7 & 9 \\
\hline Female (\%) & 1 & 1 & 1 & 2 \\
\hline $\begin{array}{l}\text { Five or more fru } \\
\text { and vegetables } \\
\text { per day }(\%)\end{array}$ & 97 & 92 & 95 & 91 \\
\hline
\end{tabular}

FIGURE 2. Percentage of deaths due to selected risk factors in four Caribbean Community countries, 2002

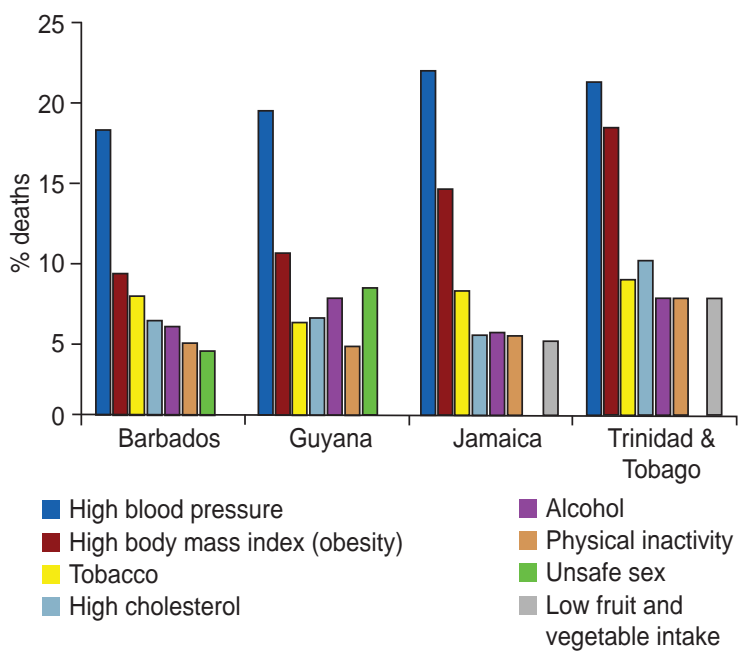

Source: Personal communication from Colin Mather to George Alleyne.

\section{SUCCESSFUL INTERVENTIONS}

In the United States and Canada, between 1971 and 1993, cardiovascular mortality declined by $3 \%-4 \%$ annually, with two-thirds of the decline from reduced incidence and one-third from a reduced case fatality rate (17-19).

The World Health Organization (WHO) goal of an annual $2 \%$ decline in projected CNCD mortality rates is based on the successes in these and other highincome countries (20). If these goals are met, $80 \%$ of the years of life gained would accrue to those $<70$ years old and $57 \%$ to those $<60$ years old $(21)$.

\section{PRIMARY PREVENTION}

In 1974, Batten introduced the concept of nondirectivity in community health programs-the revolu- tionary idea of empowering communities to diagnose and solve their own problems (22). Newell's 1975 seminal publication Health by the people articulated and promoted the concepts of primary health care, equity, and respect for community voices (23). These concepts underpin health promotion and disease management strategies at population and individual levels as necessary and effective interventions $(24,25)$.

The population approach has had mixed results. Several community-based randomized trials in the 1970s and 1980s targeting multiple risk factors showed a decline in cardiovascular disease mortality but less than expected (26). Yet, there have been significant successes in other studies-for example, the North Karelia Project (27), the Multiple Risk Factor Intervention Trial (28), and the lifestyle program in Mauritius (29) all used the health promotion approach. The evidence is that lifestyle interventions are effective in primary prevention of diabetes $(30,31)$ and in prevention of cardiovascular diseases $(32,33)$ including among adults who are obese (34).

Regular exercise programs have an independent effect of reducing the risk of all-cause mortality by up to $30 \%$ (35) and are cost-effective (36). Being sedentary doubles mortality from cardiovascular disease, diabetes, and obesity. Indirect benefits of regular exercise include reduced interpersonal violence, risk taking, and social isolation (37).

The evidence recommends primary prevention across the life span through healthy diets, physical activity, avoidance of tobacco and non abuse of alcohol (10). Health promotion strategies are enhanced by societal interventions, policy changes, and community programs to create a supportive environment "to make the right choice the easy choice."

Because of the burden of CNCDs in the Americas, and the inadequacies of the response, the Pan American Health Organization (PAHO) has developed a regional strategy and plan of action on an integrated approach to prevention and control of chronic diseases, including diet, physical activity, and health. This plan is informed by WHO resolutions and programs and has the goal of enhancing PAHO support to member states for CNCD prevention and control (38).

Efforts to improve the health status of populations in Latin America and the Caribbean have often been less than successful because of inadequate resource allocation and misuse and poor integration and coordination in both the public and private health sectors (39).

\section{HEALTH PROMOTION IN THE CARIBBEAN}

At their 13th meeting in 1993, the CARICOM Ministers of Health recognized the regions' prior successes in controlling infectious diseases but observed that current health challenges are more complexbased on social, economic, and behavioral factorsand require a new approach. Therefore, they called for formulation of the Caribbean Charter for Health 
Promotion, which was drafted later that year (40), building on the Ottawa Charter (41). The six strategies to be utilized were: formulating healthy public policy, reorienting health services, empowering communities to achieve wellbeing, creating supportive environments, developing and increasing personal health skills, and building alliances with special emphasis on the media.

The Caribbean already has a strong history of successful cooperation in health (42), including eradicating poliomyelitis, measles, and rubella (43). The Caribbean Cooperation in Health now in its third iteration (CCH3), is a mechanism to unite CARICOM countries in a common goal and strategy to improve health and wellbeing. The first of the five project goals for $\mathrm{CCH} 3$ is to create a healthy Caribbean environment conducive to promoting the health of its people and visitors (44).

\section{CARICOM HEADS OF GOVERNMENT AND CNCD SUMMIT}

This cooperation was again manifest when CARICOM convened a "first in the world" summit of heads of government to address CNCDs in September 2007 and issued the Port-of-Spain Declaration "Uniting to Stop the Epidemic of Chronic Non-Communicable Diseases in the Caribbean" (45).

This declaration fully endorsed the intersectoral, population-based approach to reducing risk factors for chronic diseases, with 14 of the 15 articles calling on "all of society" to advance health promotion and disease prevention collectively. The declaration states in part:

- That we will provide incentives for comprehensive public education programs in support of wellness, healthy life-style changes, improved self-management of CNCDs and embrace the role of the media as a responsible partner in all our efforts to prevent and control CNCDs

- Implementation of comprehensive and integrated preventive and control strategies at the individual, family, community, national and regional levels and through collaborative programmes, partnerships and policies supported by governments, private sectors, non governmental organizations (NGOs) and our other social, regional and international partners, strategies will contribute to the reduction of the burdens of CNCDs

- We hereby declare the second Saturday in September "Caribbean Wellness Day," in commemoration of this landmark Summit.

\section{CARIBBEAN WELLNESS DAY}

Caribbean Wellness Day (CWD) celebrations were inaugurated in September 2008 and were structured to use public, private, and civil society partnerships to strengthen collaboration and advance the Caribbean Wellness Campaign. The goal is to stimu- late ongoing physical activity in communities, workplaces, and schools and to promote healthy food choices and screening in a smoke-free environment. This experience is unique in that it is multicountry and multisectoral and is designed as a catalyst for sustained health promotion activities in the countries.

Prior experiences in establishing multicountry activities in health promotion have been mainly in the nature of specific "days" and the evidence is that the impact of these days is ephemeral. There is little evidence of impact evaluation of such days. For example, in 2002, WHO celebrated World Health Day with the theme "Move for Health" with activities in 148 countries, which resulted in increased awareness of physical activity, empowering communities, and building and enhancing networks. However, it was not until the month after World Health Day, at the WHO World Health Assembly in May, that a resolution was passed urging member states to sustain these activities by celebrating a Move for Health Day each year (37). The Agita Mundo Network, a nongovernmental organization (NGO) partner with the Move for Health Day, is most actively promoting the health and social benefits of at least 30 minutes of moderate physical activity every day (46).

\section{REGIONAL SUPPORTS}

CWD, mandated by the CARICOM heads of government, was fostered by the regional institutions $\mathrm{PAHO} / \mathrm{WHO}$ and CARICOM. The goals achieved by these CWD celebrations include enhancing public, private, and civil society partnerships; being a catalyst for sustained physical activity initiatives; and raising awareness of healthy lifestyle options.

$\mathrm{PAHO} / \mathrm{WHO}$ and CARICOM collaborated with CWD coordinators appointed by the Ministries of Health and promoted the formation of intersectoral CWD committees in countries. Regional support included a website (www.paho.org/cwd09) with CNCD information, promotional materials, fact sheets, and recommendations for activities to mobilize schools, workplaces, faith organizations, and the health sector. Regional products for Caribbean branding of CWD included the slogan and logo "Love That Body" (Figure $3)$, posters, stickers, a jingle, and public service announcements. These regional products were distributed to and used in all countries and were made available on the website.

The main themes were as follows:

- No tobacco: half of regular users will die from tobacco,

- Exercise 30 minutes per day: cut your heart attack risk in half,

- Less salt, less fat, and less fried food: don't add salt at the table,

- Check your blood pressure: the silent killer,

- No harmful use of alcohol: a major cause of injuries and chronic diseases. 
FIGURE 3. Caribbean Wellness Day slogan and logo on sticker, 2009

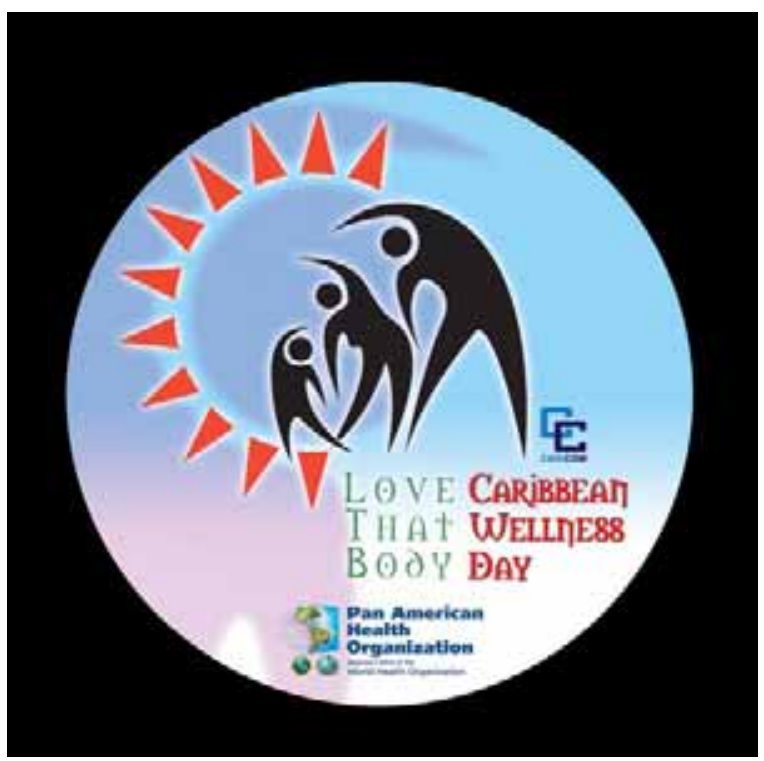

\section{MEDIA AND COMMUNICATIONS}

In advance of the celebrations, press releases and press conferences were held by PAHO, CARICOM, and individual countries. In Jamaica, the Prime Minister hosted a press conference to launch CWD 2009.

\section{COUNTRY OWNERSHIP}

The countries of the region have embraced these celebrations, which have now become the public face of the Heads of Government CNCD Summit Declaration. By 2009, the second year of the celebrations, 18 of the 20 CARICOM countries celebrated with a range of multifocal activities; 10 of the 18 countries had activities in more than half their parishes and administrative regions, compared with 2008, when celebrations were chiefly limited to the capital cities.

Countries have taken ownership of CWD. An average budget of US\$22 000 from the government in each country was assigned and supplemented by private sector support. Regional products were adapted and adopted in countries. For example, the slogan "Love That Body" was adapted to "Love My Body"; "Love That Body-Yours and Mine"; and "Love That Body, Move That Body." Six countries produced tshirts, caps, bags, and posters with the CWD slogan and logo; Bermuda circulated a brochure to every household with screening guidelines.

Countries added their own local flavor to the celebrations. For example, the Bahamas included a "Junkanoo Rush Out," with costumed revelers and local music. In Trinidad and Tobago, calypsonians led school children in dance and exercise routines. Three countries introduced "take a fruit to school/work to share" campaigns to encourage healthy eating. In five countries, public-private collaboration with the health ministry, supermarkets, and food vendors presented healthier choices. Rastafarians provided samples of their low-salt, vegetarian meals. In Saint Vincent and the Grenadines, the First Caribbean International Bank partnered with the Ministry of Health to offer a day of screening for chronic diseases for its customers and staff. In 14 countries, there were comprehensive screening activities for chronic diseases, including measuring blood pressure, height and weight, cholesterol, and glucose level with referrals as necessary.

\section{POLITICAL SUPPORT}

The President of Suriname, 10 prime ministers, and all 18 ministers of health participated. One parliamentarian has committed to leading his constituents on monthly walks. The wife of the previous Prime Minister of Barbados heads a physical activity commission to enhance sustainability, which complements the Barbados National CNCD Commission established 3 years earlier.

\section{PARTNERSHIPS AND ALLIANCES}

In 2009, sectoral mobilization enhanced the involvement and participation of the faith community, private sector and civil society, especially health NGOs and service clubs. They participated in the planning and execution, which energized the existing and nascent intersectoral CNCD commissions.

CWD has raised the profile of $C N C D$ prevention in countries and increased the opportunity for popular participation in healthy public policies. Citizens who have been exposed to the benefits from exercising on blocked roads are more likely to demand cycle paths and safe public spaces for exercise.

\section{CATALYST FOR ONGOING PHYSICAL ACTIVITY}

"Every Day Should Be Wellness Day" was a theme of the celebrations. It is recognized that one day of physical activity will not affect the epidemic of chronic diseases. So CWD multisectoral teams in countries have been tasked with implementing sustainable activities to facilitate behavior change at the population level.

Trinidad and Tobago has been most successful in this regard. Starting on Caribbean Wellness Day 2008, the community of Diego Martin introduced the Caribbean's first sustained "cyclovía" (47) with the local name "Family Fitness Sunday." The community, in collaboration with a private company and supported by government agencies, has been blocking roads for 4 hours every Sunday morning for 2 years, providing space for children and adults to dance exercise, socialize, and sample healthy products. 
In the British Virgin Islands, the Minister of Health launched "Walk Into It," a year-long walking initiative. Grenada's "Biggest Loser Title" was a 4month workplace competition for reducing collective body weights through health and exercise. Five countries-Trinidad and Tobago, Saint Lucia, Antigua, British Virgin Islands, and Saint Vincent and the Grenadines-have introduced and sustained ongoing physical activity in primary health centers. Seven other countries have introduced and sustained weekly or monthly walks or dancing events.

These sustained events, triggered by CWD celebrations, demonstrate the value of CWD since its inception in 2008 .

\section{EVALUATION AND DOCUMENTATION}

Fourteen of the 18 participating countries completed a structured evaluation, and 16 have media reports and a photo gallery posted on the website (48). The evaluation metrics included budget, participation of partners, geographic spread of CWD, utilization of regional branding products, media coverage, plans for sustaining activities, and recommendations. A video report of CWD 2009 is also available online (49). Health outcomes will depend on the "dose," penetration, and sustainability of the intervention (50). Success will be demonstrated by reductions in risk factors of unhealthy diet, physical inactivity, tobacco use and alcohol abuse, and subsequent reductions in incidence and prevalence of CNCDs. The countries will measure outcomes with the STEPS CNCD risk factor surveillance surveys (51) and reports of the CNCD minimum data set.

A comprehensive evaluation including process and outcome evaluation should be developed, conducted, and reported soon. Joint evaluations using credible evidence of changes in health and social status are needed to facilitate achievement of collaboratively defined goals, justify the conclusions reached, and share the lessons learned (52).

\section{CHARACTERISTICS OF SUCCESS}

The CWD celebration seeks a novel way to engage many countries for a common purpose with a common vehicle, guided and supported by regional organizations, and based on a mandate from heads of government. The focus is on sustaining the interventions catalyzed by the 1-day celebrations and highlighting and sharing "best practices" in program sustainability. For example, the Trinidad and Tobago "Streets for Wellness" weekly blocking of roads to facilitate community physical activity is a robust model for other countries.

Characteristics of successful mobilization at the country level include decentralization of organization and celebrations to the parish, county, and district level; early release of funds; use of music, sports, or entertainment personalities to lead exercise sessions; blocking roads to create the environment for commu- nity participation; and active involvement of civil society and other branches of government.

Specific communities, schools, workplaces, and faith organizations were targeted for empowerment and alliances were built to create supportive environments for physical activity. The main messages were reinforced in all products and messages and were designed to improve individuals' health knowledge and skills.

\section{PROSPECTS FOR THE FUTURE}

For survival and growth, these partnerships and programs need institutionalization and the creation of infrastructures for strategic planning and sustainability; for example, national intersectoral CNCD commissions should be established in countries that do not have them. These bodies should lead in transforming CWD into an ongoing Caribbean Wellness Campaign.

Acknowledgments. I thank Mirta Roses, Director of PAHO; Prime Minister Hon. Denzil Douglas, CARICOM Minister of Health; and CARICOM Secretary General E. Carrington for the messages they sent. I also thank the country teams coordinated by the ministries of health and their private sector and civil society partners, Eddie Greene and the officials of the CARICOM secretariat, James Hospedales, Gilles Collette and the staff of the NCD and PIN units at PAHO headquarters, and PAHO staff in the Caribbean. The Caribbean Association of Industry and Commerce and media provided valuable support. Professor Trevor Hassell and the Healthy Caribbean Coalition mobilized the civil society. Financial and technical support for the summit and follow-up was provided by the Public Health Agency of Canada and the Canadian International Development Agency. Sir George Alleyne, Director Emeritus of PAHO, was helpful in preparing and reviewing the manuscript.

\section{SINOPSIS}

\section{Día del Bienestar en el Caribe: movilización de una región para la prevención y el control de las enfermedades crónicas no transmisibles}

Los estados miembros de la Comunidad del Caribe (CARICOM) tienen la prevalencia más alta de enfermedades crónicas no transmisibles de la Región de las Américas. Los jefes de gobierno de la CARICOM emitieron la Declaración de Puerto España "Unidos contra las enfermedades no transmisibles en el Caribe", en la que se promueve la adopción de métodos intersectoriales y poblacionales y, en conmemoración de la cumbre, se propone la instauración del segundo sábado de septiembre como el "Día del Bienestar en el Caribe". Ese día, celebrado por primera vez en septiembre del 2008, tiene la finalidad de fortalecer las asociaciones públicas, privadas y de la sociedad civil, y promover actividades multinacionales y multisectoriales en respaldo del bienestar. En el 2009, el segundo año de esta celebración, 18 
de los 20 países de la CARICOM adoptaron y celebraron actividades multifacéticas y multifocales, como una manera de catalizar la actividad física sostenida, la elección de alimentos sanos y los exámenes médicos en un entorno sin humo de tabaco. El apoyo para la organización de estas celebraciones y la creación de su imagen institucional en el Caribe provino de la Organización Panamericana de la Salud/Organización Mundial de la Salud y de la CARICOM. Para medir los re- sultados se utilizarán indicadores con respecto a los procesos y las contribuciones, además de la vigilancia de los factores de riesgo de las enfermedades crónicas no transmisibles.

Palabras clave: enfermedad crónica; promoción de la salud; participación comunitaria; participación públicoprivada; Indias Occidentales.

\section{REFERENCES}

1. CARICOM member states. Caribbean Community Secretariat; Georgetown, Guyana: 2010. Available from: http:// www.caricom.org/jsp/community/me mber_states.jsp?menu=community. Accessed 25 November 2010.

2. PAHO health situation in the Americas, basic indicators. Washington, DC: $\mathrm{PAHO}$ 2009. Available from: http://new.paho. org/hq/dmdocuments/2009/BI_ENG_ 2009.pdf. Accessed 25 November 2010.

3. World Bank data and statistics. Washington, DC: World Bank; 2008. Available from: http://web.worldbank.org/ WBSITE/EXTERNAL/COUNTRIES/ LACEXT/0,,contentMDK:22117191 pa gePK:146736 piPK:146830 the SitePK:258554,00.html. Accessed 25 November 2010.

4. Hennis AJ, Fraser HS, Jonnalagadda R, Fuller J, Chaturvedi N. Explanations for the high risk of diabetes-related amputation in a Caribbean population of black African descent and potential for prevention. Diabetes Care. 2004;27(11): 2636-41.

5. Hambleton IR, Jonnalagadda R, Davis CR, Fraser HS, Chaturvedi N, Hennis AJ. All-cause mortality after diabetesrelated amputation in Barbados: a prospective case-control study. Diabetes Care. 2009;32(8):e100.

6. Asaria P, Chisholm D, Mathers C, Ezzati M, Beaglehole R. Chronic disease prevention: health effects and financial costs of strategies to reduce salt intake and control tobacco use. Lancet. 2007; 370(9604):2044-53.

7. Beaglehole R, Bonita R. Global public health: a scorecard. Lancet. 2008;372 (9654):1988-96

8. Working document for the regional summit on chronic non-communicable diseases (CNCDs). Port-of-Spain, Trinidad and Tobago; 15 September 2007.

9. Kaplan GA, Keil JE. Socioeconomic factors and cardiovascular disease: a review of the literature. Circulation. 1993;88(4Pt1):1973-98.

10. World Health Organization. Preventing chronic diseases-a vital investment. Geneva: WHO; 2005. Available from: http://www.who.int/chp/chronic_dis ease_report/en/index.html. Accessed 25 November 2010.

11. Forrester T. Historic and early life origins of hypertension in Africans. J Nutr. 2004;134(1):211-6.
12. Freeman $V$, Fraser $H$, Forrester $T$, Wilks $\mathrm{R}$, Cruickshank J, Rotimi C, et al. A comparative study of hypertension prevalence, awareness, treatment and control rates in St Lucia, Jamaica and Barbados. J Hypertens. 1996;14(4):495-501.

13. Pyne HH, Claeson M, Correia M. Gender and alcohol consumption and alcoholrelated problems in Latin America and the Caribbean. International Bank for Reconstruction and Development/The World Bank, 2002. World Bank discussion paper 433. Rev Panam Salud Publica. 2002;12(1):59-62.

14. Henry F. Healthy Caribbean Coalition. Healthy Caribbean 2008, Conference presentations. Kingston, Jamaica: Caribbean Food \& Nutrition Institute, PAHO; 2008. Available from: http://www. healthycaribbean.org/presentations/hc 2008/index.html. Accessed 25 November 2010 .

15. Henry FJ. The obesity epidemic-a major threat to Caribbean development: the case for public policies. Cajanus. 2004;37(1):3-21.

16. Global burden of disease. Geneva: WHO; 2004. Available from: http:// www.who.int/healthinfo/global_bur den_disease/GlobalHealthRisks_re port_part2.pdf. Accessed 25 November 2010.

17. Ergin A, Muntner P, Sherwin R, He J. Secular trends in cardiovascular disease mortality, incidence, and case fatality rates in adults in the United States. Am J Med. 2004;117(4):219-27.

18. Sytkowski PA, Kannel WB, D'Agostino RB. Changes in risk factors and the decline in mortality from cardiovascular disease. The Framingham Heart Study. N Engl J Med. 1990;322(23): 1635-41.

19. Bata IR, Gregor RD, Eastwood BJ, Wolf HK. Trends in the incidence of acute myocardial infarction between 1984 and 1993: The Halifax County MONICA Project. Can J Cardiol. 2000; 16(5):589-95.

20. World Health Organization. Prevention and control of noncommunicable diseases: implementation of the global strategy. Geneva: WHO; 2008.

21. Beaglehole R, Ebrahim S, Reddy S, Voûte J, Leeder S, Chronic Disease Action Group. Prevention of chronic diseases: a call to action. Lancet. 2007; 370(9605):2152-7.
22. Batten TR. The major issues and future direction of community development. Community Dev J. 1974;9(2):96-103.

23. Newell KW, ed. Health by the people. Geneva: WHO; 1975.

24. Rose G. Sick individuals and sick populations. Int J Epidemiol. 1985;14:32-8.

25. Yusuf S, Reddy S, Ounpuu S, Anand S Global burden of cardiovascular diseases. Part II: variations in cardiovascular disease by specific ethnic groups and geographic regions and prevention strategies. Circulation. 2001;104(23): 2855-64.

26. World Health Organisation European Collaborative Group. European collaborative trial of multifactorial prevention of coronary heart disease: final report on the 6-year results. Lancet. 1986;1(8486): $869-72$.

27. Vartiainen E, Puska P, Pekkanen J, Tuomilehto J, Jousilahti P. Changes in risk factors explain changes in mortality from ischaemic heart disease in Finland. Br Med J. 1994;309(6946):23-7.

28. Dowse GK, Gareeboo H, Alberti KG, Zimmet P, Tuomilehto J, Purran A, et al. Mortality after 16 years for participants randomized to the Multiple Risk Factor Intervention Trial. Circulation. 1996;94 (5):946-51.

29. Chitson P, Collins VR. Changes in population cholesterol concentrations and other cardiovascular risk factor levels after five years of the non-communicable disease intervention programme in Mauritius. Mauritius Non-communicable Disease Study Group. Br Med J. 1995;311(7015):1255-9.

30. Diabetes Prevention Program Research Group. Reduction in the incidence of type 2 diabetes with lifestyle intervention or metformin. N Engl J Med. 2002; 346(6):393-403.

31. Lindström J, Ilanne-Parikka P, Peltonen M, Aunola S, Eriksson JG, Hemiö K, et al. Sustained reduction in the incidence of type 2 diabetes by lifestyle intervention: follow-up of the Finnish Diabetes Prevention Study. Lancet. 2006;368(9548): 1673-9.

32. Appel LJ. Lifestyle modification as a means to prevent and treat high blood pressure. J Am Soc Nephrol. 2003;14(7 Suppl 2):S99-102.

33. Maruthur NM, Wang NY, Appel LJ. Lifestyle interventions reduce coronary heart disease risk: results from the 
PREMIER Trial. Circulation. 2009;119 (15):2026-31.

34. Weinstein AR, Sesso HD, Lee IM, Rexrode KM, Cook NR, Manson JE, et al. The joint effects of physical activity and body mass index on coronary heart disease risk in women. Arch Intern Med. 2008;168(8):884-90.

35. Rosengren A, Wilhelmsen L. Physical activity protects against coronary death and deaths from all causes in middle-aged men. Evidence from a 20-year follow-up of the primary prevention study in Göteborg. Ann Epidemiol. 1997;7(1): 69-75.

36. Probstfield JL. How cost-effective are new preventive strategies for cardiovascular disease? Am J Cardiol. 2003;91 (10):22G-7G.

37. World Health Organization. World Health Day 2002: move for health. Geneva: WHO; 2002. Available from: http://whqlibdoc.who.int/hq/2002/W HO_NMH_NPH_WHD_02.13.pdf. Accessed 25 November 2010.

38. La actividad de la OPS en el campo de las enfermedades no transmisibles. Rev Panam Salud Publica. 1997;2(6):420-7.

39. de Souza JMP, Raczynski D, Patino GB, Ribeiro AT, Feliu E. Notes on health care planning in Latin America and the Caribbean. Rev Saude Publica. 1977;11 (2):279-83.

40. Caribbean Charter for Health Promotion. Washington, DC: PAHO; 1993. Available from: http://www.cepis.ops-oms.org/
bvsdeps/fulltext/declarationCar.pdf. Accessed 12 December 2008.

41. The Ottawa Charter for Health Promotion. Geneva: WHO; 1986. Available from: http://www.who.int/healthpro motion/conferences/previous/ottawa/ en/index1.html. Accessed 25 November 2010 .

42. Nassau Declaration on Health 2001. The Health of the Region is the Wealth of the Region. Georgetown, Guyana: Caribbean Community Secretariat; 2001. Available from: http://www.caricom. org/jsp/communications/meetings_ statements/nassau_declaration_on_ health.jsp?menu=communications. Accessed 25 November 2010.

43. Irons B, Smith HC, Carrasco PA, De Quadros C. The immunisation programme in the Caribbean. Caribb Health. 1999;2(3):9-11.

44. Caribbean Cooperation in Health Phase III (CCH III). Investing in Health for Sustainable Development. 2010. Available from: http://new.paho.org/ocpc/ index.php?option=com_content\&task= view\&id=97\&Itemid=1. Accessed 25 November 2010.

45. Declaration of Port-of-Spain: uniting to stop the epidemic of chronic non-communicable diseases. Georgetown, Guyana: Caribbean Community Secretariat; 2007. Available from: http://www.cari com.org/jsp/communications/meet ings_statements/declaration_port_of_sp ain_chronic_ncds.jsp. Accessed 25 November 2010

46. Agita Mundo. Available from: http:// www.agitamundo.org/site_en.htm. Accessed 25 November 2010.

47. Ciclovía. Available from: http://en. wikipedia.org/wiki/Ciclov\%C3\%ADa. Accessed 25 November 2010

48. Caribbean Wellness Day website. Available from: www.paho.org/cwd09. Accessed 25 November 2010.

49. Video report of Caribbean Wellness Day. Available from: http://www. youtube.com/watch?v=AErpKC_NYQ 0 . Accessed 25 November 2010.

50. Hawe P, Noort M, King L, Jordens C. Multiplying health gains: the critical role of capacity-building within health promotion programs. Health Policy. 1997;39(1):29-42.

51. World Health Organization, Division of Chronic Diseases and Health Promotion. STEPwise approach to surveillance. Geneva: WHO; 2004. Available from: http://www.who.int/chp/steps/en/. Accessed 25 November 2010.

52. Butterfoss FD. Evaluating partnerships to prevent and manage chronic disease. Prev Chronic Dis. 2009;6(2):A64.

Manuscript received on 23 February 2010. Revised version accepted for publication on 28 July 2010 